deal with his fellow men could be attributed to his poychiatric forebears.

\section{Social Events}

The Annual Dinner was held in the Great Hall of St Bartholomew's Hospital on Wednesday, 6 July. Dr W. A. Heaton-Ward proposed the toast of 'The Guests' and Sir John Richardson replied. The Toast of 'The Royal College of Psychiatrists' was proposed by the Rt Hon David Ennals, M.P., Secretary of State for the Social Services, and the President replied.

On Tuesday, 5 July, over two hundred members and guests attended a Reception at the Royal College of Psychiatrists.

Members' wives and husbands were accompanied by Mrs Linford Rees at a performance by the Royal Ballet on Wednesday $6 \mathrm{July}$, and on a visit to the Silver Vaults, Chancery Lane, on Thursday, 7 July.

\title{
ELEGTION OF FELLOWS
}

The following Members have been elected to the Fellowship:

E. Anthony, D. M. Bassa, J. S. Bearcroft, A. W. Beard, I. S. Berg, Dorothy Bicknell, B. Blackwell, S. Bockner, A. C. Brown, D. G. Brown, J. Buckman, J. R. M. Copeland, J. A. Corbett, F. M. S. Dabbagh, R. J. Daly, H. A. Darwish, G. I. Davies, K. A. Day, S. R. Dean, P. T. d'Orban, H. B. Durost, Elizabeth Easton, D. Eccleston, J. P. Farrell, M. M. Feldman, J. J. Fennelly, H. C. Ferguson, K. M. Fraser, D. E. Friedman, M. Glasser, M. D. A. Heller, G. F. D.
Hesseltine, D. C. James, P. F. Johnson, K. Jones, Muriel Jones, A. C. Kaeser, N. J. Kothari, L. C. Kreeger, G. A. Levinson, C. J. Lucas, E. G. Lucas, N. Lukianowicz, D. J. McClure, W. R. McLeod, S. B. Mahapatra, F. M. M. Mai, G. Milner, J. H. Orr, J. R. Palmer, R. A. Parry, P. M. Ployé, L. B. Raschka, O. R. Schmalzbach, G. Sedman, H. G. S. Sergeant, H. Stewart, E. Stonehill, H. R. Suliman, F. G. Thorpe, J. E. Varley, V. K. Varma, D. A. Walk, C. J. Wardle, H. C. White, R. W. Whiteley, E. A. M. Wood, W. B. Wright and A. Zarrabi.

\section{PHOTOCOPIES OF ARTICLES IN 'THE READING LIST IN PSYGHIATRY'}

The reference on page $I$ of this List to 'those contemplating ordering photocopies' means ordering through the Librarian of a medical or psychiatric library who has access to a range of journals and books either through their own collection or the British Library at Boston Spa. Neither Headley Brothers Ltd nor The Royal College of Psychiatrists can supply these photocopies. 